\title{
Two alternatives for the synthesis of pyrrolo[1,2-a]quinoxaline derivatives
}

\author{
Y. Harrak, S. Weber, A. B. Gómez, G. Rosell, and M. D. Pujol* \\ Laboratori de Química Farmacèutica. Facultat de Farmàcia. Universitat de Barcelona. Av. \\ Diagonal 643. 08028-Barcelona, Spain \\ E-mail: mdpujol@ub.edu
}

\section{Dedicated to Professor Joan Bosch on the occasion of his $60^{\text {th }}$ anniversary}

\begin{abstract}
The 4,5-dihydropyrrolo[1,2-a]quinoxaline system was prepared through two different reaction sequences. The first method is based on the intramolecular reductive amination of the corresponding nitrophenylpyrrole-carbaldehyde intermediate, whereas an alternative synthesis involves as key step, the intramolecular substitution of an aromatic fluoride by a secondary amine.
\end{abstract}

Keywords: Pyrroles, pyrrolo-quinoxaline, defluoro-cyclization, polycyclic heterocyclic compounds

\section{Introduction}

The pyrrolo[1,2-a]quinoxaline system is the skeleton of several heterocyclic compounds possessing interesting biological activity. This nucleus substituted at the C-4 with alkylpiperazines gives highly selective agonist affinity for the serotonine receptors. ${ }^{1}$ Pyrrolo[1,2a]quinoxaline-2- or -4-carboxylic acid hydrazide derivatives ${ }^{2}$ showed high anti-tuberculosis activity, while 2-(aminomethyl)-4-phenylpyrrolo[1,2- $a$ ]quinoxalines revealed a central dopamine antagonist activity. ${ }^{3}$ More recently, $N$-sulfonyl-pyrrolo[1,2-a]quinoxalines were prepared as estrogenic receptor modulators ${ }^{4}$ and 4-hydrazino-pyrroloquinoxalines demonstrated anticancer activity and therapeutic properties influencing the angiogenesis function. ${ }^{5}$

Whereas the preparation of pyrrolo[1,2-a]quinoxalin-4-ones has been described, ${ }^{6}$ a bibliographical search for the pyrrolo[1,2-a]quinoxalines revealed surprisingly that only a few synthetic procedures have been reported previously for these heterocyclic analogues, i.e. reduction of the lactam derivatives, ${ }^{7}$ 1,3-dipolar cycloaddition of quinoxalium $N$-ylides to alkenes $^{8}$ and alkynes ${ }^{9}$ or reaction of 1-(2-aminophenyl)pyrroles with aldehydes. ${ }^{10}$ 
As part of a program aimed at the discovery of novel polycyclic compounds with therapeutic potential and following our previous interest in the synthesis of tricyclic pyrrole condensed systems such as pyrrolo[2,1-c][1,4]benzoxazines, ${ }^{11}$ we now wish to report two different sequences for the synthesis of its bioisosteric heterocycle pyrrolo[1,2-a]quinoxaline; both pyrrolo-benzoxazines and pyrrolo-quinoxalines are considered useful scaffolds in medicinal chemistry.

\section{Results and Discussion}

Following previous work of our laboratory on the synthesis of pyrrolo[2,1-c][1,4]benzoxazines ${ }^{11}$ we report here two different and useful synthetic approaches to the synthesis of pyrrolo[1,2a]quinoxalines from the corresponding commercially available 2-substituted anilines (Scheme 1).
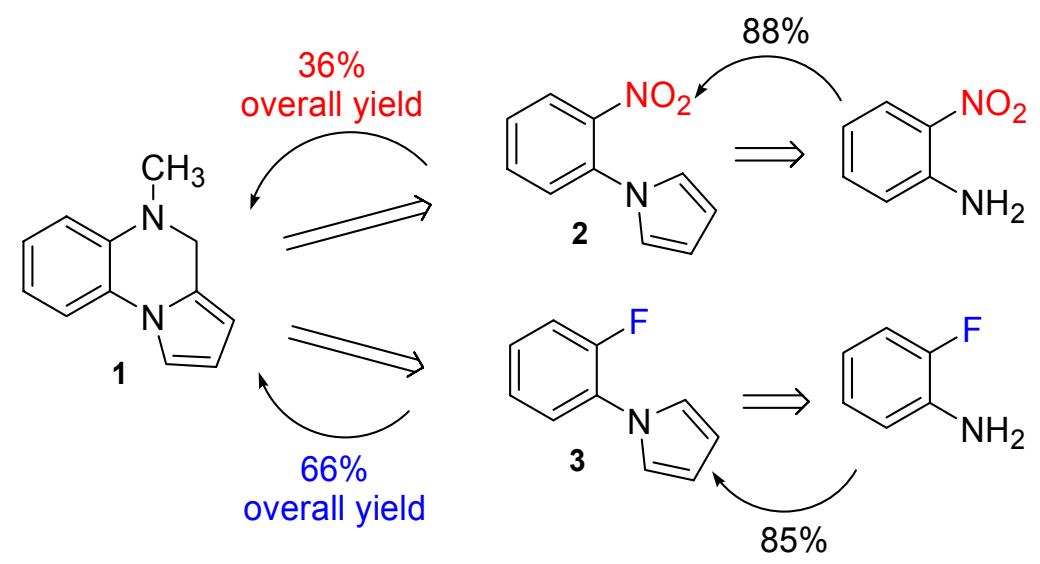

\section{Scheme 1}

The key starting intermediates 2 and $\mathbf{3}^{11}$ were prepared by reacting 2-nitroaniline or 2fluoroaniline with 2,5-dimethoxytetrahydrofuran (DMTHF) in the presence of glacial acetic acid by a modified Paal-Knorr procedure ${ }^{12-13}$ known as the Clauson-Kaas reaction ${ }^{14}$ in $88 \%$ and $85 \%$ yield, respectively. The introduction of a formyl group at C-2 of the condensed heterocyclic system, under Vilsmeier-Haak conditions, affords the aldehydes $\mathbf{4}$ and $\mathbf{9}$ in acceptable yields (70\% for 4 and $85 \%$ for 9 ) (Scheme 2 and 3 ). 


\section{Method 1}

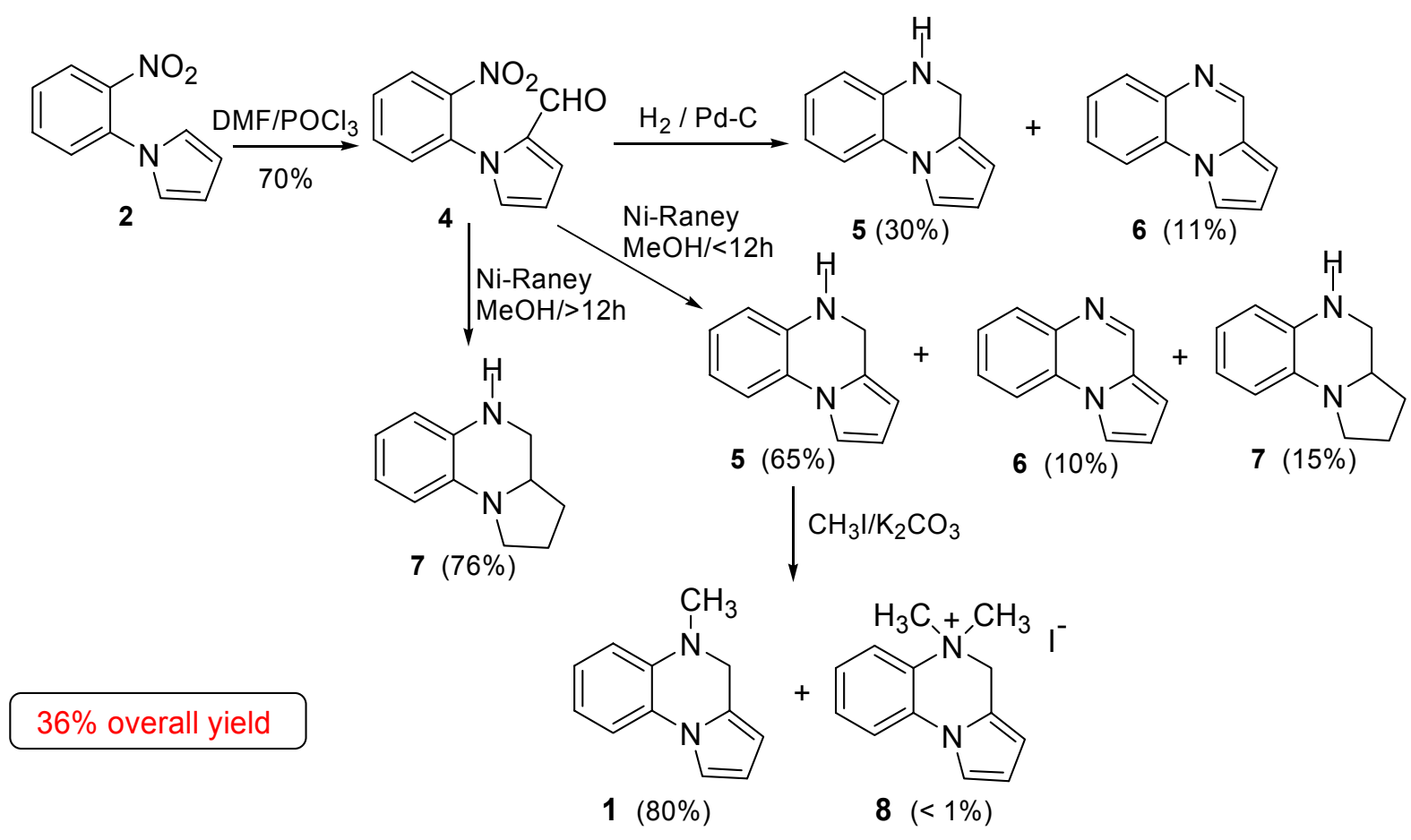

\section{Scheme 2}

The nitroaldehyde 4 was reductively cyclized using catalytic hydrogenation; optimum yield (65\% for compound 5) was obtained using Ni-Raney in methanol, under hydrogen atmosphere, for a period of time less than $12 \mathrm{~h}$. Prolonged hydrogenation reaction time (more than $12 \mathrm{~h}$ ) leads exclusively to reduced hexahydropyrroloquinoxaline 7 in $76 \%$ yield. When $10 \% \mathrm{Pd} / \mathrm{C}$ was used as catalyst in ethyl acetate, a mixture of the desired pyrrolo-quinoxaline $5(30 \%)$ and the analogue 6 (11\%) was obtained (Scheme 2).

Methylation of the pyrrolo-quinoxaline 5 was carried out in acetone with $\mathrm{CH}_{3} \mathrm{I}$ in the presence of $\mathrm{K}_{2} \mathrm{CO}_{3}$ at room temperature to give the $N$-methylquinoxaline $\mathbf{1}$ in good yield (80\%). In this alkylation process, traces of the corresponding quinoxalium iodide were also isolated (8). It is noteworthy that the compound 1 was previously prepared by Mannich reaction from $N$-(2(methylamino)phenyl)pyrrole in only $22 \%$ yield. $^{15}$

The pyrrolo-quinoxaline 1 was preferably prepared in higher yields by an alternative synthesis (method 2) in which 2-fluoroaniline was chosen as starting material. The formylation of the $N$-(2-fluorophenyl)pyrrole 3 and subsequent treatment with methylamine, followed by reduction of the intermediate imine with $\mathrm{NaBH}_{4}$ provided the secondary amine $\mathbf{1 0}$ in good yield (Scheme 3). 


\section{Method 2}

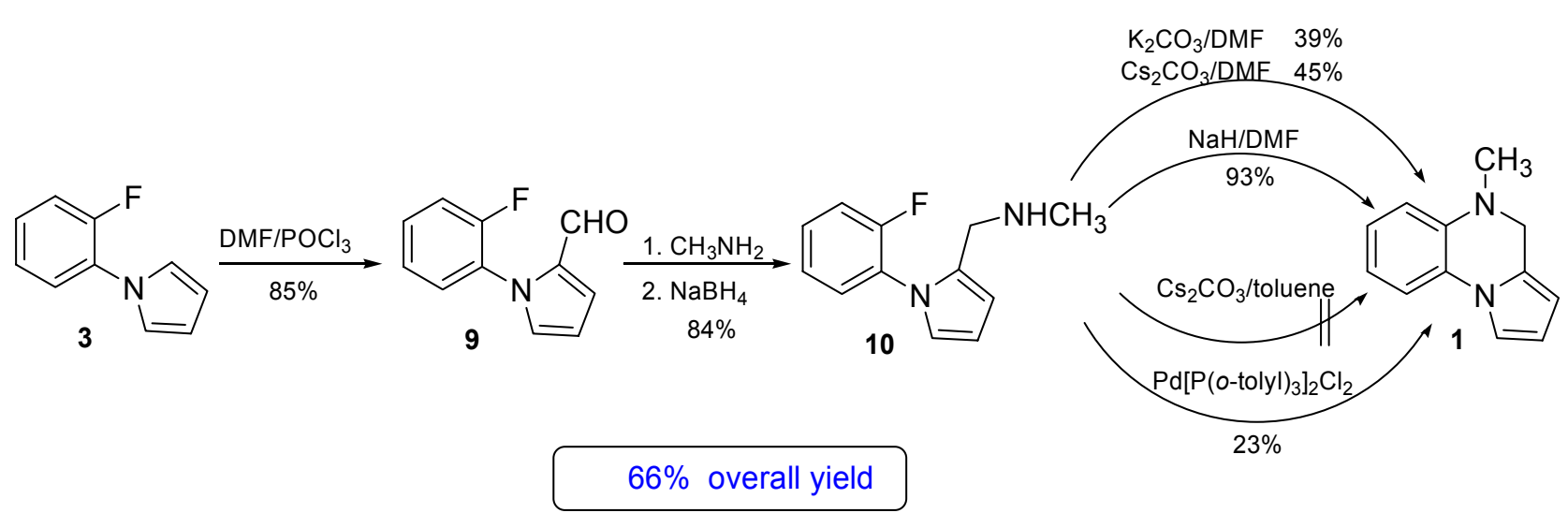

\section{Scheme 3}

Several attempts were made to optimize the intramolecular cyclization: first treatment of the methylamine $\mathbf{1 0}$ in refluxing toluene under the coupling reaction conditions ${ }^{16}$ catalyzed by $\mathrm{Pd}\left[\mathrm{P}(o \text {-tolyl })_{3}\right]_{2} \mathrm{Cl}_{2} / \mathrm{BINAP} / \mathrm{Cs}_{2} \mathrm{CO}_{3}$ gave the pyrrolo-quinoxaline 1 in low yields $(<30 \%)$. Further insight into this reaction was obtained by treatment of the amine $\mathbf{1 0}$ with $\mathrm{Cs}_{2} \mathrm{CO}_{3}(1 \mathrm{eq})$ as a base without catalyst. The absence of reaction under these conditions suggests the implication of catalyst and ligand in the cyclization process or that the solvent is inadequate for the nucleophilic aromatic substitution.

The pyrrolo-quinoxaline $\mathbf{1}$ was successfully obtained by treatment of the methylamine $\mathbf{1 0}$ with $\mathrm{NaH}$ in DMF by direct intramolecular nucleophilic displacement of the fluoride anion by the secondary amine (93\%). Other bases as anhydrous $\mathrm{Cs}_{2} \mathrm{CO}_{3}$ and $\mathrm{K}_{2} \mathrm{CO}_{3}$ in excess (5 eq) in DMF gave the quinoxaline in low yields ( $45 \%$ and $39 \%$ respectively). These results revealed that an excess of base is necessary and that DMF is the appropriate solvent for the intramolecular aromatic nucleophilic substitution.

\section{Conclusion}

The two synthetic methods described herein allow the preparation of the pyrrolo-quinoxaline $\mathbf{1}$ in each three steps, but whereas the method 1 provide the pyrrolo-quinoxaline in $36 \%$ overall yield, the second sequence involving formylation, reductive amination and cyclization give the desired compound in $66 \%$ overall yield. It is interesting to note that method 1 provides next to the desired dihydropyrrolo-quinoxaline, also the pyrrolo-quinoxaline $\mathbf{6}$ and the hexahydropyrroloquinoxaline 7, interesting and useful intermediates in organic synthesis and in medicinal chemistry. 


\section{Experimental Section}

General Methods. Melting points were obtained on an MFB-595010M Gallenkamp apparatus in open capillary tubes and are uncorrected. IR spectra were obtained using a FTIR Perkin-Elmer 1600 Infrared Spectrophotometer. Only noteworthy IR absorptions are listed $\left(\mathrm{cm}^{-1}\right) .{ }^{1} \mathrm{H}$ and ${ }^{13} \mathrm{C}$ NMR spectra were recorded on a Varian Gemini-200 (200 and 50.3 MHz respectively) or Varian Gemini-300 (300 and $75.5 \mathrm{MHz}$ ) Instrument using $\mathrm{CDCl}_{3}$ as solvent with tetramethylsilane as internal standard or $\left(\mathrm{CD}_{3}\right)_{2} \mathrm{CO}$. Other ${ }^{1} \mathrm{H}-\mathrm{NMR}$ spectra and heterocorrelation ${ }^{1} \mathrm{H}-{ }^{13} \mathrm{C}$ (HMQC and HMBC) experiments were recorded on a Varian VXR-500 (500 MHz). Mass spectra were recorded on a Helwett-Packard 5988-A. Column chromatography was performed with silica gel (E. Merck, 70-230 mesh). Reactions were monitored by TLC using $0.25 \mathrm{~mm}$ silica gel F-254 (E. Merck). Microanalysis was determined on a Carlo Erba-1106 analyser. All reagents were of commercially quality or were purified before use. Organic solvents were of analytical grade or were purified by standard procedures. Commercial products were obtained from Sigma-Aldrich.

\section{Method 1. N-Methyl-4,5-dihydropyrrolo[1,2-a]quinoxaline (1). 5,5-Dimethyl-4H-} pyrrolo[1,2-a]quinoxalium iodide (8). To a solution of quinoxaline $5(250 \mathrm{mg}, 1.47 \mathrm{mmol})$ in $30 \mathrm{~mL}$ of dry acetone was added $\mathrm{K}_{2} \mathrm{CO}_{3}(305 \mathrm{mg}, 2.2 \mathrm{mmol})$ and methyl iodide $(0.18 \mathrm{~mL}, 2.94$ $\mathrm{mmol})$. The resulting mixture was stirred at room temperature for $10 \mathrm{~h}$. Then, acetone was removed and the residue was diluted with water $(20 \mathrm{~mL})$ and extracted with ether $(3 \times 15 \mathrm{~mL})$. The organic phases were dried over $\mathrm{Na}_{2} \mathrm{SO}_{4}$, filtered and the solvent removed under vacuum to give a yellow solid, which was purified by silica gel column chromatography eluting with a mixture of hexane/ethyl acetate 90:10 affording the title compound as a yellow solid (216 $\mathrm{mg}$, $1.18 \mathrm{mmol}, 80 \%$ yield). (See the reference 15 for experimental details reported previously for $\mathbf{1}$, such as mp: 65-66 (methanol)).

Mp: 67-68 ${ }^{\circ} \mathrm{C}$ (hexane / ethyl acetate). IR (KBr) c cm$^{-1}$ : $1645(\mathrm{C}=\mathrm{H}) ; 1517(\mathrm{C}=\mathrm{C}) ; 1377(\mathrm{C}-\mathrm{N})$. ${ }^{1} \mathrm{H}$ NMR $\left(\mathrm{CDCl}_{3}, 300 \mathrm{MHz}\right) \delta(\mathrm{ppm}), 2.38\left(\mathrm{~s}, 3 \mathrm{H}, \mathrm{CH}_{3}-\mathrm{N}\right) ; 3.63\left(\mathrm{~s}, 2 \mathrm{H}, \mathrm{CH}_{2}-\mathrm{N}\right) ; 5.98(\mathrm{~m}, 1 \mathrm{H}, \mathrm{H}-$ 3); 6.30 (m, 1H, H-2); 7.06-7.10 (m, 1H, H-6); 7.11 (m, 2H, H-7, H-8); 7.14 (dd, $J_{l}=3, J_{2}=1.4$ $\mathrm{Hz}, 1 \mathrm{H}, \mathrm{H}-1), 7.28\left(\mathrm{dd}, J_{1}=7.8, J_{2}=1.4 \mathrm{~Hz}, 1 \mathrm{H}, \mathrm{H}-9\right) .{ }^{13} \mathrm{C} \mathrm{NMR}\left(\mathrm{CDCl}_{3}, 50.3 \mathrm{MHz}\right) \delta(\mathrm{ppm})$, $38.4\left(\mathrm{CH}_{3}\right) ; 49.1\left(\mathrm{CH}_{2}\right) ; 103.6(\mathrm{CH}, \mathrm{C}-3) ; 109.9(\mathrm{CH}, \mathrm{C}-2) ; 112.7(\mathrm{CH}, \mathrm{C}-6) ; 113.8(\mathrm{CH}, \mathrm{C}-1)$; 114.4 (CH, C-9); 118.5 (CH, C-7); 124.7 (CH, C-8'); 125.7 (C, C-3a); 126.4 (C, C-5a); 138.2 (C, C-9a). Anal. Calcd for $\mathrm{C}_{12} \mathrm{H}_{12} \mathrm{~N}_{2}$ : C, 78.23; H, 6.57; N, 15.21\%. Found: C, 78.59; H, 6.23; N, $15.58 \%$.

Finally, the column chromatography was eluted with ethyl acetate $100 \%$ to give only traces of the quinoxalium salt 8 , which was assigned structure by ${ }^{1} \mathrm{H}$ NMR spectroscopy and mass spectra. $\mathrm{SM}(\mathrm{EI}) \mathrm{m} / \mathrm{z}(\%): 327$ (22) $[\mathrm{MH}+] .{ }^{1} \mathrm{H}$ NMR (DMSO-d 6 , $\left.300 \mathrm{MHz}\right) \delta(\mathrm{ppm}), 3.42\left(\mathrm{~s}, 3 \mathrm{H}, \mathrm{CH}_{3}-\right.$ $\mathrm{N}) ; 3.52\left(\mathrm{~s}, 3 \mathrm{H}, \mathrm{CH}_{3}-\mathrm{N}\right) ; 5,12\left(\mathrm{~s}, 2 \mathrm{H}, \mathrm{CH}_{2}-\mathrm{N}\right) ; 6.44(\mathrm{~m}, 2 \mathrm{H}, \mathrm{H}-2, \mathrm{H}-3) ; 7.41(\mathrm{t}, J=8 \mathrm{~Hz}, 1 \mathrm{H}, \mathrm{H}-$ 8); 7.62 (t, $J=8 \mathrm{~Hz}, 1 \mathrm{H}, \mathrm{H}-7) ; 7.76(\mathrm{~m}, 1 \mathrm{H}, \mathrm{H}-1) ; 8.01\left(\mathrm{dd}, J_{1}=8.6 \mathrm{~Hz}, J_{2}=1.6 \mathrm{~Hz}, 2 \mathrm{H}, \mathrm{H}-6, \mathrm{H}-\right.$ 9). 
$\mathbf{N}$-(2-Nitrophenyl)pyrrole (2). Following the general procedure reported previously by V. Nacci et al. ${ }^{17}$ after purification by column chromatography, the nitropyrrole $\mathbf{2}$ was obtained as a yellow oil in $88 \%$ yield. Nacci et all. reported only the ${ }^{1} \mathrm{H}$ NMR data for $\mathbf{2}$ and these are incomplete.

IR $(\mathrm{KBr}) \cup \mathrm{cm}^{-1}: 1530(\mathrm{C}=\mathrm{C}) ; 1355(\mathrm{C}=\mathrm{N}) .{ }^{1} \mathrm{H}$ NMR $\left(\mathrm{CDCl}_{3}, 200 \mathrm{MHz}\right) \delta(\mathrm{ppm}), 6.37(\mathrm{t}, J=2.2$ $\mathrm{Hz}, 2 \mathrm{H}, \mathrm{H}-3, \mathrm{H}-4) ; 6.80$ (t, $J=2.2 \mathrm{~Hz}, 2 \mathrm{H}, \mathrm{H}-2, \mathrm{H}-5) ; 7.50$ (m, 1H, H-4'); 7.62 (d, J=8 Hz, 1H,

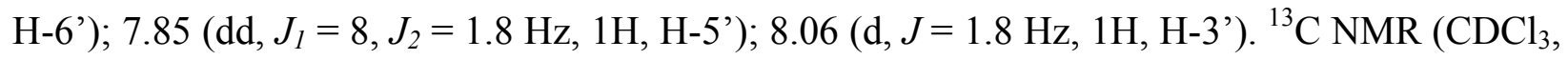
$50.3 \mathrm{MHz}) \delta(\mathrm{ppm}), 110.9(\mathrm{CH}, \mathrm{C}-3, \mathrm{C}-4) ; 121.2(\mathrm{CH}, \mathrm{C}-2, \mathrm{C}-5) ; 124.9\left(\mathrm{CH}, \mathrm{C}-6\right.$ '); $127.5^{*}(\mathrm{CH}$, C-3'); 127.7* (CH, C-4'); 133.2 (CH, C-5'); 134.0 (C, C-1'); 145.0 (C, C-2').

$*$ interchangeable

$\boldsymbol{N}$-(2-Fluorophenyl)pyrrole (3). For the experimental procedure and analytical data, see reference 11.

$\mathrm{N}$-(2-Nitrophenyl) pyrrole-2-carbaldehyde (4). To a solution of distilled DMF (0.43 mL, 5.84 $\mathrm{mmol}$ ) and $\mathrm{POCl}_{3}(895 \mathrm{mg}, 5.84 \mathrm{mmol})$ was added the nitrophenylpyrrole 2 (1 g, $\left.5.31 \mathrm{mmol}\right)$. The resulting mixture was stirred at room temperature for $3 \mathrm{~h}$. The crude reaction was treated with saturated solution of $\mathrm{Na}_{2} \mathrm{CO}_{3}$ and extracted with ether $(3 \times 20 \mathrm{~mL})$. The organic phase was dried over $\mathrm{Na}_{2} \mathrm{SO}_{4}$, filtered and the filtrate was evaporated. The crude of reaction was purified by column chromatography of silica gel eluting with hexane/ethyl acetate to give the aldehyde 4 in $70 \%$ yield ( $805 \mathrm{mg}, 3.72 \mathrm{mmol}) . \mathrm{Mp}: 128-130{ }^{\circ} \mathrm{C}$ (hexane/ethyl acetate). IR (KBr) v cm${ }^{-1}: 1652$ $(\mathrm{C}=\mathrm{O}) ; 1530(\mathrm{C}=\mathrm{C}) ; 1354\left(\mathrm{C}-\mathrm{NO}_{2}\right) .{ }^{1} \mathrm{H}$ NMR $\left(\mathrm{CDCl}_{3}, 200 \mathrm{MHz}\right) \delta(\mathrm{ppm}), 6.49(\mathrm{~m}, 1 \mathrm{H}, \mathrm{H}-4)$; 7.02 (m, 1H, H-3); 7.13 (m, 1H, H-5); 7.43 (d, J=8.8 Hz, 1H, H-6'); 7.68 (m, 2H, H-4', H-5'); 8.20 (d, $J=8.8 \mathrm{~Hz}, 1 \mathrm{H}, \mathrm{H}-3$ '); 9.51 (s, 1H, CHO). ${ }^{13} \mathrm{C} \mathrm{NMR}\left(\mathrm{CDCl}_{3}, 50.3 \mathrm{MHz}\right) \delta(\mathrm{ppm}), 111.6$ (CH, C-4); 123.9 (CH, C-2); 124.8 (CH, C-5); 125.2 (CH, C-3); 129.4 (CH, C-6'); 129.5 (CH, C3’); 131.1 (CH, C-4'); 133.5 (C, C-1'); 133.6 (CH, C-5'); 146.0 (C, C-2'); 178.6 (C, CHO).

4,5-Dihydropyrrolo[1,2-a]quinoxaline (5). Pyrrolo[1,2-a]quinoxaline (6). 1,2,3,3a,4,5Hexahydropyrrolo[1,2-a]quinoxaline (7). A solution of nitrocarbaldehyde 4 (500 mg, 2.31 $\mathrm{mmol})$ in methanol $(30 \mathrm{~mL})$ was introduced in a hydrogenation flask and Ni-Raney $(300 \mathrm{mg}$, $50 \%$ in water) was added. The resulting mixture was stirred under a hydrogen atmosphere during 4h. Then, the suspension was filtered and the methanol of the liquid phase was removed under vacuum. The crude product was purified by silica gel column chromatography and eluted with a mixture of hexane and ethyl acetate (90:10) to give a white solid (255 mg, $1.5 \mathrm{mmol}, 65 \%$ yield) corresponding to the 4,5-dihydropyrrolo[1,2-a]quinoxaline (5). Using a mixture of hexane and ethyl acetate (85:15), the 1,2,3,3a,4,5-hexahydropyrrolo[1,2-a]quinoxaline (7) (60 $\mathrm{mg}, 0.34$ mmol, $15 \%$ ) was obtained as a white solid and finally, the elution with a mixture of hexane and ethyl acetate (80:20) gave the pyrrolo[1,2-a]quinoxaline (6) as a white solid (39 $\mathrm{mg}, 0.23 \mathrm{mmol}$, $10 \%)$.

Compound 7 was obtained in $76 \%$ yield, following the same conditions, after a prolonged reaction time (more than $12 \mathrm{~h}$ ).

Using $10 \% \mathrm{Pd} / \mathrm{C}$ as a catalyst in ethyl acetate, a mixture of the pyrroloquinoxaline $5(30 \%)$ and the pyrroloquinoxaline $\mathbf{6}(11 \%)$ was obtained after purification by column chromatography eluting with hexane/ethyl acetate. 
4,5-Dihydropyrrolo[1,2-a]quinoxaline (5). Mp: 114-116 ${ }^{\circ} \mathrm{C}$ (hexane/ethyl acetate). IR (KBr) $\mathrm{U}$ $\mathrm{cm}^{-1}: 3368(\mathrm{NH}) ; 1490(\mathrm{C}=\mathrm{C}) ; 1294(\mathrm{C}-\mathrm{N}) .{ }^{1} \mathrm{H}$ NMR $\left(\mathrm{CDCl}_{3}, 200 \mathrm{MHz}\right) \delta(\mathrm{ppm}), 3.90(\mathrm{bs}, 1 \mathrm{H}$, $\mathrm{NH}) ; 4.40\left(\mathrm{~s}, 2 \mathrm{H}, \mathrm{CH}_{2}-\mathrm{N}\right) ; 5.98(\mathrm{~m}, 1 \mathrm{H}, \mathrm{H}-3) ; 6.30\left(\mathrm{t}, J_{1}=3 \mathrm{~Hz}, 1 \mathrm{H}, \mathrm{H}-2\right) ; 6.72\left(\mathrm{dd}, J_{1}=7.8, J_{2}\right.$ $=1.4 \mathrm{~Hz}, 1 \mathrm{H}, \mathrm{H}-6) ; 6.80\left(\mathrm{dt}, J_{1}=7.8, J_{2}=1.6 \mathrm{~Hz}, 1 \mathrm{H}, \mathrm{H}-7\right) ; 6.95\left(\mathrm{dd}, J_{1}=7.2, J_{2}=1.4 \mathrm{~Hz}, 1 \mathrm{H}\right.$, $\mathrm{H}-8) ; 7.14\left(\mathrm{dd}, J_{1}=3, J_{2}=1.4 \mathrm{~Hz}, 1 \mathrm{H}, \mathrm{H}-1\right) ; 7.28\left(\mathrm{dd}, J_{1}=7.8, J_{2}=1.6 \mathrm{~Hz}, 1 \mathrm{H}, \mathrm{H}-9\right) .{ }^{13} \mathrm{C} \mathrm{NMR}$ $\left(\mathrm{CDCl}_{3}, 50.3 \mathrm{MHz}\right) \delta(\mathrm{ppm}), 40.8\left(\mathrm{CH}_{2}-\mathrm{N}\right) ; 110.0(\mathrm{CH}, \mathrm{C}-2) ; 114.1(\mathrm{CH}, \mathrm{C}-1) ; 114.7(\mathrm{CH}, \mathrm{C}-9)$; 115.3 (CH, C-6); 119.0 (CH, C-7); 124.4 (CH, C-8); 125.4 (C, C-3a); 125.6 (C, C-5a); 136.3 (C, C-9a). Anal. Calcd for $\mathrm{C}_{11} \mathrm{H}_{10} \mathrm{~N}_{2}$ : C, 77.62; H, 5.92; N, 16.46\%. Found: C, 77.97; H, 5.65; N, $16.84 \%$.

Pyrrolo[1,2-a]quinoxaline (6). Mp: $137-139{ }^{\circ} \mathrm{C}$ (hexane/ethyl acetate). IR (KBr) $v \mathrm{~cm}^{-1}: 1546$ $(\mathrm{C}=\mathrm{N}) ; 1454(\mathrm{C}=\mathrm{C}) ; 1233(\mathrm{C}-\mathrm{N}) .{ }^{1} \mathrm{H}$ NMR $\left(\mathrm{CDCl}_{3}, 200 \mathrm{MHz}\right) \delta(\mathrm{ppm}), 6.93$ (m, 2H, H-2, H-3);

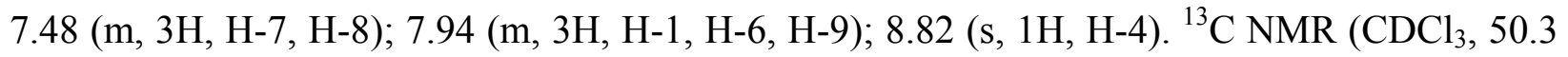
$\mathrm{MHz}) \delta(\mathrm{ppm}), 107.1(\mathrm{CH}, \mathrm{C}-3) ; 113.7(\mathrm{CH}, \mathrm{C}-2) ; 114.1(\mathrm{CH}, \mathrm{C}-6) ; 125.1(\mathrm{CH}, \mathrm{C}-1) ; 126.3(\mathrm{CH}$, C-7); 127.7 (CH, C-8); 127.9 (C, C-3a); 130.0 (C, C-5a); 135.7 (C, C-9a); 145.7 (CH, C-4). Anal. Calcd for $\mathrm{C}_{11} \mathrm{H}_{8} \mathrm{~N}_{2}$ : C, 78.55; H, 4.79; N, 16.66\%. Found: C, 78.77; H, 4.65; N, 16.34\%.

1,2,3,3a,4,5-Hexahydropyrrolo[1,2-a]quinoxaline (7). Mp: $99-101^{\circ} \mathrm{C}$ (hexane/ethyl acetate). IR $(\mathrm{KBr}) \cup \mathrm{cm}^{-1}: 3341(\mathrm{NH}) ; 1597(\mathrm{C}=\mathrm{CH}) ; 1518(\mathrm{C}=\mathrm{C}) ; 1318(\mathrm{C}-\mathrm{N}) .{ }^{1} \mathrm{H}$ NMR $\left(\mathrm{CDCl}_{3}, 200\right.$ MHz) $\delta(\mathrm{ppm}), 1.42$ (m, 1H, H-3); 2.02 (m, 3H, 2 x H-2, H-3); 2.80 (bs, 1H, H-3a); 3.23 (m, 2H, 2 x H-1); 3.51 (m, 2H, H-4); 6.41 (d, J=8.4Hz, H-9); 6.54 (m, 2H, H-7, H-8); 6.62 (m, 1H, H6). ${ }^{13} \mathrm{C} \mathrm{NMR}\left(\mathrm{CDCl}_{3}, 50.3 \mathrm{MHz}\right) \delta(\mathrm{ppm}), 23.6(\mathrm{C}-3) ; 29.9(\mathrm{C}-2) ; 46.1(\mathrm{C}-1) ; 47.3(\mathrm{C}-4) ; 56.7$ (CH, C-3a); 110.9 (CH, C-6); 113.5 (CH, C-9); 116.3 (CH, C-8); 119.4 (CH, C-7); 132.6 (C, C5a); 135.0 (C, C-9a). Anal. Calcd for $\mathrm{C}_{11} \mathrm{H}_{14} \mathrm{~N}_{2}$ : C, 75.82; H, 8.10; N, 16.08\%. Found: C, 75.54; $\mathrm{H}, 7.91 ; \mathrm{N}, 16.42 \%$.

$\mathrm{N}$-(2-Fluorophenyl)pyrrole-2-carbaldehyde (9). For the experimental procedure and analytical data, see reference 11.

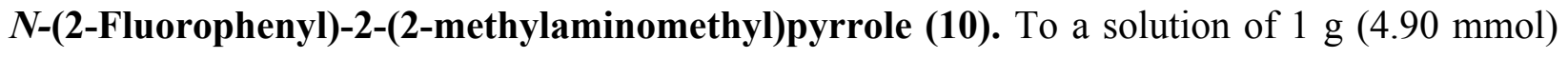
of $\mathrm{N}$-(2-fluorophenyl)pyrrole-2-carbaldehyde 9 in toluene $(10 \mathrm{~mL})$, methylamine $(5 \mathrm{~mL})$ and a catalytic amount of $p$-toluenesulfonic acid (PTSA) were added. The mixture was stirred at reflux using a refrigerant and a Dean Stark system for $24 \mathrm{~h}$. The reaction was monitored by TLC using hexane/ethyl acetate 7:3 as eluent. After complete consumption of the starting aldehyde, the mixture was cooled to room temperature and the solvent was removed under vacuum. Then, methanol $(12 \mathrm{~mL})$ and $100 \mathrm{mg}(2.64 \mathrm{mmol})$ of $\mathrm{NaBH}_{4}$ were added to the crude reaction mixture and the resulting mixture was stirred at room temperature for $2 \mathrm{~h}$. Methanol was removed, water $(15 \mathrm{~mL})$ and dichloromethane $(20 \mathrm{~mL})$ were added. The crude reaction mixture was extracted with dichloromethane, the organic layers were dried over $\mathrm{Na}_{2} \mathrm{SO}_{4}$, filtered and the solvent evaporated. The residue was purified by silica gel column chromatography using hexane/ethyl acetate $90 / 10$ as eluent. Finally the residue was recollected in methanol and the solvent was removed under vacuum to give $0.840 \mathrm{mg}(4.11 \mathrm{mmol}$, yield $84 \%)$ of the methylamine 10 as colorless oil. 
IR (KBr) ט (cm-1): $3424(\mathrm{NH}), 1511(\mathrm{C}=\mathrm{C}), 1372(\mathrm{C}-\mathrm{N}) ; 742(\mathrm{C}-\mathrm{F}) .{ }^{1} \mathrm{H}$ NMR $\left(\mathrm{CDCl}_{3}, 300\right.$ $\mathrm{MHz}) \delta(\mathrm{ppm}), 2.97$ (s, 3H, $\left.\mathrm{CH}_{3}-\mathrm{N}\right) ; 4.25$ (s, 2H, $\left.\mathrm{CH}_{2}-\mathrm{N}\right) ; 6.08$ (m, 1H, H-4); 6.40 (m, 1H, H-3); 6.85 (m, 1H, H-5'); 6.92 (m, 1H, H-3'); 7.22 (t, J=6 Hz, H-4'); 7.24 (m, 1H, H-5); 7,36 (m, 1H, H-6'). ${ }^{13} \mathrm{C}$ NMR $\left(\mathrm{CDCl}_{3}, 50.3 \mathrm{MHz}\right) \delta(\mathrm{ppm}), 36.6\left(\mathrm{CH}_{3}\right) ; 49.4\left(\mathrm{CH}_{2}\right) ; 103.9(\mathrm{CH}, \mathrm{C}-3) ; 112.6$ $(\mathrm{CH}, \mathrm{C}-4) ; 113.0(\mathrm{CH}, \mathrm{C}-5) ; 114.1\left(\mathrm{CH}, J=22 \mathrm{~Hz}, \mathrm{C}-3\right.$ '); $114.6\left(\mathrm{CH}, J=14 \mathrm{~Hz}, \mathrm{C}-4^{\prime}\right) ; 118.7$ (CH, C-5'); 125.0 (CH, C-6'); 125.8 (C, C-2); 138.5 (C, C-1'); 155,0 (C, J = $\left.254 \mathrm{~Hz}, \mathrm{C}-2^{\prime}\right)$. Anal. Calcd for $\mathrm{C}_{12} \mathrm{H}_{13} \mathrm{FN}_{2} .1 / 2 \mathrm{CH}_{3} \mathrm{OH}$ : C, 63.53; H, 6.40; N, 11.86\%. Found: C, 63.88; H, 6.02; N, $11.51 \%$.

Method 2. $N$-Methyl-4,5dihydropyrrolo[1,2-a]quinoxaline (1). Procedure a). To a suspension of $\mathrm{Cs}_{2} \mathrm{CO}_{3}(130 \mathrm{mg}, 0.40 \mathrm{mmol})$, BINAP $(0.5 \mathrm{~mol} \%)$ and $\operatorname{Pd}\left[\mathrm{P}(o \text {-tolyl })_{3}\right]_{2} \mathrm{Cl}_{2}(0.1 \mathrm{~mol} \%)$ in toluene $(1 \mathrm{~mL})$ the corresponding methylamine $10(80 \mathrm{mg}, 0.39 \mathrm{mmol})$ was added and the resulting mixture was stirred and heated at $100^{\circ} \mathrm{C}$ under argon for $12 \mathrm{~h}$.

The mixture was cooled to room temperature, the solvent was removed and the crude product was purified by silica gel column chromatography using hexane / ethyl acetate 90:10 as eluent. The title compound was isolated as a white solid in $23 \%$ yield (17 mg, $0.02 \mathrm{mmol})$.

Procedure b). To a solution of methylamine 10 (160 mg, $0.78 \mathrm{mmol})$ in freshly distilled DMF (4 $\mathrm{mL}$ ), $\mathrm{NaH}(50 \mathrm{mg}, 2.08 \mathrm{mmol}$ ) was slowly added under an argon atmosphere. The resulting mixture was heated at $100{ }^{\circ} \mathrm{C}$ for $48 \mathrm{~h}$. The crude reaction mixture was cooled to room temperature and diluted with water and ice $(30 \mathrm{~mL})$, and then $2 \mathrm{~N} \mathrm{HCl}$ was added until $\mathrm{pH}$ 5-6. The mixture was extracted with ether $(3 \times 20 \mathrm{~mL})$. Then the organic phase was washed with water, dried over $\mathrm{Na}_{2} \mathrm{SO}_{4}$, filtered and the solvent was removed under vacuum. The crude reaction mixture was purified by silica gel chromatography column using a mixture of hexane/ethyl acetate $90: 10$ as eluent. An amount of $133.5 \mathrm{mg}(0.73 \mathrm{mmol}) 93 \%$ of the title compound as a white solid was obtained.

Following the above indicated conditions and using $\mathrm{Cs}_{2} \mathrm{CO}_{3}$ or $\mathrm{K}_{2} \mathrm{CO}_{3}$ (excess 5 equiv) instead of $\mathrm{NaH}$ the same quinoxaline 1 was obtained in 45 and $39 \%$ yield, respectively.

\section{Acknowledgements}

The financial support from the University of Barcelona (Spain) (Ajuts a la recerca 2006) and the Departament d'Universitats, Recerca I Societat de la Informació de la Generalitat de Catalunya, Spain (2005-SGR-00180) is gratefully acknowledged.

\section{References}

1. Campiani, G.; Nacci, V.; Corelli, Anzini, M. Synth. Commun. 1991, 21, 1567. (b) Campiani, G.; Morelli, E.; Gemma, S.; Nacci, V.; Butini, S.; Hamon, M.; Novellino, E.; Greco, G.; Cagnotto, A.; Goegan, M.; Cervo, L.; Dalla Valle, F.; Fracasso, C.; Caccia, S.; Mennini, T. 
J. Med. Chem. 1999, 42, 4362. (c) Prunier, H.; Rault, S.; Lancelot, J.-C.; Robba, M.; Renard, P.; Delagrange, P.; Pfeiffer, B.; Caignard, D. H.; Misslin, R.; Guardiola-Lemaitre, B.; Hamon, M. J. Med. Chem. 1997, 40, 1808.

2. Guillon, J.; Reynolds, R. C.; Leger, J.-M.; Guie, M. A.; Massip, S.; Dallemagne, P.; Jarry, C. J. Enz. Inh. Med. Chem. 2004, 19, 489.

3. Guillon, J.; Boulouard, M.; Lisowski, V.; Stiebing, S.; Lelong, V.; Dallemagne, P.; Rault, S. J.Pharm. Pharmacol. 2000, 52, 1369.

4. Sabatucci, J. P.; Ye, F.; Mahaney, P. E. PCT Int. Appl. 2006 WO 2006068928.

5. Neamati, N.; Garofalo, A. U.S. Pat. Appl. Publ. 2006. US 2006142294.

6. Rotas, G.; Kimbaris, A.; Varvounis, G. Tetrahedron 2004, 60, 10825, and references cited therein.

7. Artico, M.; De Martino, G.; Nacci, V. Annali di Chimica 1967, 57, 1431.

8. Zhou, J.; Zhang, L.; Hu, Y.; Hu, H. J. Chem. Res. Synopses 1999, 9, 552.

9. Zhang, X.-C. ; Huang, W.-Y. Tetrahedron 1998, 54, 12465.

10. Abonia, R.; Insuasty, B.; Quiroga, J.; Kolshorn, H.; Meier, H. J. Heterocyclic Chem. 2001, 38, 671 .

11. Sánchez, I.; Pujol, M. D. Tetrahedron 1999, 55, 5593.

12. Paal, C. Chem. Ber. 1884, 17, 2757.

13. Knorr, L. Chem. Ber. 1884, 17, 2863.

14. Clauson-Kaas, N.; Tyle, Z. Acta Chem. Scand. 1952, 6, 667.

15. Raines, S.; Chai, S. Y.; Palopoli, F. P. J. Heterocyclic Chem. 1976, 13, 711.

16. Collins, I. J. Chem. Soc., Perkin Trans 1, 2000, 2845.

17. Campiani, G.; Nacci, V.; Corelli, Anzini, M. Synth. Commun. 1991, 21, 1567. 